Kelemen Roland:

\title{
A KIVÉTELES HATALOM KONTINENTÁLIS MODELLJÉNEK EREDETI RENDSZEREI \\ - A NÉMET ÉS AZ OSZTRÁK KIVÉTELES HATALMI STRUKTÚRA KIALAKULÁSA ÉS FEJLŐDÉSE AZ ELSŐ VILÁGHÁBORÚIG
}

\author{
DOI: $\underline{10.35926 / \mathrm{HSZ} .2021 .3 .10}$
}

\begin{abstract}
ÖSSZEFOGLALÓ: Jelen tanulmányban a szerző a kivételes hatalom kontinentális történeti modelljének kialakulását és főbb jellemzőit mutatja be. A polgári átalakulás harmadik hullámához tartozó német és osztrák államban megkésetten jelentek meg a jogállami intézmények, így a kivételes hatalmi szabályok is. A korábban más országokban kialakult rendszereket saját alkotmányos berendezkedésükhöz és hagyományaikhoz igazithatták, igy jött létre egy sajátképi különleges jogrendi modell, melynek jellemzöi többek között az alkotmányos determináltság, a végrehajtói túlsúly, a katonai igazgatás kiterjesztése a polgári szervekre és az eredendő rendeletalkotási lehetőség. A tanulmány a német és az osztrák kivételes hatalmi rendszert mutatja be a kialakulásától az első világháború időszakáig.

KULCSSZAVAK: kontinentális modell, német, osztrák, szükségrendelet, alapjog korlátozása, katonai közigazgatás
\end{abstract}

\section{BEVEZETÉS}

A kialakult polgári államalakulatoknak választ kellett adniuk az újfajta vagy jelentős átalakuláson átesett biztonsági kihívásokra, kockázatokra. ${ }^{1}$ Ennek első mozzanata az volt, hogy az államnak azonosítania kellett az általánostól eltérő határszituációkat, majd pedig fószabályként jogállami keretek között meg kellett keresni azok megoldásainak leghatékonyabb eszközeit. Ezek pedig olyan speciális, a végrehajtó hatalom egyes hatalmi jegyeinek kiterjesztését jelentették, amelyek a jogfejlődés szintje okán vagy a normál jogrend keretei közötti egyes decíziós [döntési - a szerk.] jogkörök kiszélesítését vonták maguk után (például karhatalmi fellépés eszközparkja), vagy az ostromállapottól - hiszen azt egy speciális történelmi helyzet szülte - eltérő, új típusú kivételes hatalmi szabályanyag létrehozását eredményezték.

\footnotetext{
Az államok és különösen Magyarország védelmi és biztonsági helyzetekre való reakciói, felkészülése kapcsán bővebben lásd Farkas Ádám (2019a): A [hon]védelmi alkotmány kialakulása a polgári Magyarországon 1867-1944. Zrínyi Kiadó, Budapest, 2019; Farkas Ádám (2019b): Az állam fegyveres védelmének alapvonalai. Katonai Nemzetbiztonsági Szolgálat, Budapest, 2019; Farkas Ádám: A totalitás kora? Magyar Katonai Jogi és Hadijogi Társaság, Budapest, 2018. http://www.hadijog.hu/wp-content/uploads/2018/08/FA_a_totalitas_kora_BJM_I.pdf (Letöltés időpontja: 2020. 10. 03.)
} 
Előintézményekkel találkozhatunk a német területeken is, ${ }^{2}$ de a polgári átmenet - a klaszszikus időszakához képest - késői, inkább a 19. század közepére tehető megvalósulása okán alkotmányos meghatározottságról és törvényi szabályozásról csak ekkortól beszélhetünk. Az intézmény kialakulására hatást gyakorolhatott ekkorra már a francia ostromállapoti és angol martial law típusú kivételes hatalmi rendszer. Az angol jog - bár mintaértékü intézményeket szült - a „,...kivételes állapot tekintetében azonban ily mintául vétel nem történt, mert e tekintetben a francziaországi fejlödés a saját maga lábán haladt és haladt ennek nyomán az európai szárazföld többi részeiben is a hasonló intézmények szabályozása". ${ }^{3}$ Kézenfekvő volt a francia szabályozás mintául vétele, hiszen az a napóleoni expanzió során tényleges tapasztalás tárgya lehetett, emellett pedig az alkotmányos struktúra hasonlósága is könnyebbé tette annak használatát, mint a kontinenstől eltérő angolszász gondolkodás átemelését.

Jelen tanulmányban a német és az osztrák jogállami kivételes hatalmi rendszer kialakulását mutatom be azok jellemzőivel és első világháborúig tartó fejlődési ívükkel. Ezen államok kivételes hatalmi struktúrája egy sajátos, kontinentális különleges jogrendi modellt teremtett meg, jól elkülöníthető jegyekkel az angol és az amerikai kivételes hatalmi rendszertől, valamint a klasszikus francia ostromállapoti szabályozástól.

\section{NÉMET KIVÉTELES HATALOM KIALAKULÁSA ÉS JELLEMZÖI AZ ELSŐ VILÁGHÁBORÚIG}

Az 1849-es kérészéletű frankfurti birodalmi alkotmány 197. §-a rendelkezett a kivételes hatalomról, amely azt háború vagy felkelés esetén tette elrendelhetővé. A birodalmi vagy tagállami kormány elrendelhette egyes alkotmányos alapjogok felfüggesztését (például házkutatással kapcsolatos garanciák, gyülekezési jog), ehhez viszont összminisztériumi döntésre volt szükség, amelyet a birodalmi vagy tagállami törvényhozás elé kellett terjeszteni. Ha az nem ülésezett, akkor rendelkezni kellett az összehívásáról, emellett a meghozott rendelkezések 14 napig lehettek hatályban. ${ }^{4}$

Jelentősebb hatású a porosz szabályozás, hiszen a későbbi Német Birodalom alkotmányos struktúrájába emelték annak törvényi szintjét. Poroszországban az 1848. december 5-i alkotmány 110. cikke adott felhatalmazást háború és felkelés esetére. A felhatalmazás szerint fel lehetett függeszteni vagy korlátozni az alkotmány személyi szabadságra, a magánlakás sérthetetlenségére, a törvényes bíróhoz való jogra, a gyülekezési és egyesülési jogra, valamint a sajtószabadságra vonatkozó rendelkezéseit.

Az 1850. január 31-i alkotmány 111. cikke úgy rendelkezett, hogy háború esetén az ellenség által fenyegetett vagy már részben megszállt tartományokban, illetve felkelés esetén a közbiztonság sürgető veszélyekor lehetett elrendelni a hadiállapotot, valamint szükség esetén a fenti alapjogokat korlátozni. ${ }^{5}$ A kihirdetés dob- és trombitaszóval történt, illetve

2 Például a hadúri felségjogokból levezethető jogosultságok, vagy ilyen volt a Német Szövetség tagállamon belüli veszélyhelyzetének kezelése, akár másik tagállam hadereje által. Utóbbi - a Szent Szövetséghez hasonlóan a korábbi, feudális hatalmi, politikai és társadalmi status quo fenntartása érdekében volt.

3 Polner Ödön: A háború esetére szóló kivételes hatalom alkotmányjogi jelentősége. Jogállam, 16. évf. 1917/1-2., 32.

4 Tóth Árpád: A kivételes állapot intézménye néhány burzsoá állam jogrendszerében kialakulásától az első világháború végégig. Acta Juridica et Politica 5. Fasc. 1981, 24. http://acta.bibl.u-szeged.hu/6476/1/juridpol_028_fasc_005_001054.pdf (Letöltés időpontja: 2020. 10. 03.)

5 Buza László: Az államjogi kivételes állapot II. Jogtudományi Közlöny, 50. évf. 1915/28., 313. http://real-j.mtak. hu/2183/1/JogtudomanyiKozlony_1915.pdf (Letöltés időpontja: 2020. 10. 03.) 
nyilvános hirdetmények vagy lapok útján, továbbá minden alkalommal értesíteni kellett a községi elöljárókat. ${ }^{6}$ A részletes szabályok kialakítását törvényi szintre delegálta.

A törvényi szabályozás 1851. január 4-én született meg, és az az alkotmányt követve külső és belső veszélyhelyzetet különített el. Háború esetén az ellenség által fenyegetett vagy részben megszállt területeken az érintett erödítmény parancsnoka gyakorolta a jogosítványokat az erődítmény és a hozzá tartozó területek tekintetében, míg a parancsnokló tábornok a hadtest egyéb területeire vagy annak egyes részeire. ${ }^{7}$ Belső lázadás esetében föszabályként az államminiszter rendelhette el a hadiállapotot, míg sürgös esetben - ideiglenesen - az érintett területre az ott szolgáló legmagasabb rangú katonai parancsnok. Utóbbival szemben többletfeltétel volt, hogy a polgári közigazgatás vezetőjének indítványára is szükség volt. A törvényhozást azonnal tájékoztatni kellett a kihirdetésröl és az alapjogi korlátozásról. Ha nem ültek együtt, akkor a következö ülésszakon be kellett számolni az eseményekröl. Utóbbiból látható, hogy hadiállapot esetén a törvényhozásnak lényegében csak deklaratív hatásköre volt, ami a királyi - később császári - végrehajtó hatalmi túlsúly eredménye volt.

A törvény hatásköri szabályai szükségképpeni és fakultatív jogkörökre voltak oszthatók. Az elrendelés szükségképpeni következménye volt, hogy a hadiállapot elrendelését követően az érintett területen a végrehajtó hatalom a terület katonai parancsnokára szállt, akinek utasításait a polgári közigazgatás köteles volt végrehajtani. A hadiállapot szintén szükségképpeni kelléke volt a büntető anyagi jogi szabályok szigorítása. Ennek során egyes bủncselekmények - így a gyújtogatás, az árvíz okozása, a fegyveres erők elleni cselekmények, a polgári vagy katonai hatóságok elleni erőszakos cselekmények, az álhírterjesztés, a zendülés, a tettleges ellenállás, a fogolyszöktetés - súlyosabb elbírálás alá estek.

A hadiállapot fakultatív következménye volt az alapjogi korlátozások elrendelése, amelyröl szabadon dönthetett a terület illetékes parancsnoka. Ez azt eredményezte, hogy a különböző területeken eltérő veszélyszintekhez lehetett igazítani az alapjogi korlátozást. Emellett viszont, mivel ennek meghatározása az illetékes parancsnok diszkrecionális jogköre volt, így annak habitusa, szemlélete is visszatükröződött a korlátozáson, lehetővé téve akár a visszaélésszerü hatáskörgyakorlást. Főként azért, mert a szabályozás nem állapított meg garanciális maximumot, hanem lehetővé tette a fentebb felsorolt jogok teljes felfüggesztését is.

Lehetőség volt a vegyes haditörvényszékek felállítására, amiről szintén az illetékes parancsnok rendelkezhetett. Ezek a haditörvényszékek a fenti büncselekményeken túl ítélkezhettek felségárulás, hazaárulás, emberölés, fosztogatás, vasút vagy távíró rongálása esetében is, akár civil, akár katona volt az elkövető. A törvényszékek öt tagból álltak, közülük kettőt a helységre illetékes polgári bíróság elnöke jelölt ki, hármat pedig a katonai parancsnok. Az eljáró tanács elnöke az egyik polgári bíró volt. Az eljárás szóbeli, nyilvános és a védelem megengedett volt. Jogorvoslat nem volt az ítéletekkel szemben, viszont a halálos ítéletet az illetékes parancsnoknak meg kellett erősítenie. ${ }^{8}$

A fentiek mellett a leglényegesebb és sajátképi hatáskör a kivételes rendelet megalkotásának lehetősége volt. A kivételes rendeletet az jellemezte, hogy a törvénnyel egyenértékü jogszabály volt, amelyet a törvényhozás maximum helyteleníthetett, de kizárólag az uralkodó

\footnotetext{
Uo. 314 .

Német védelmi jog fejlődését lásd bővebben Farkas Ádám - Till Szabolcs: A honvédelmi alkotmány és alkotmányosság alapkérdései Magyarországon. In: Farkas Ádám - Kádár Pál (szerk.): Magyarország katonai védelmének közjogi alapjai. Zrínyi Kiadó, Budapest, 2016, 42-45.; Farkas Ádám (2019b): i. m. 75-79.

8 Tóth: i. m. 25-26.
} 
joga és kötelezettsége volt a hatályon kívül helyezése. E jogkör korlátja csupán az volt, hogy ilyen rendelettel az alkotmányt és meghatározott törvényeket nem módosíthattak. ${ }^{9}$

A német egység létrejötte után elfogadott birodalmi alkotmány 68 . §-a alkalmazni rendelte a porosz törvényt hadiállapot esetére. Ez alól később kivételt jelentett Bajorország, ahol 1912. november 5-én saját kivételes hatalmi törvényt fogadtak el, bár az lényegében megismételte a porosz jogszabályt.

A birodalmi kivételes hatalom rendszerében az elrendelés joga a császárt illette meg a közbiztonság fenyegetettsége esetén. A fentebb bemutatott rendelkezések, tehát a Német Birodalmi kivételes hatalmi jog törzsét képezték, anélkül hogy azok teljes alkotmányhoz igazítása megtörtént volna, ugyanis például az alapjogok alkotmányos meghatározottsága a birodalmi alkotmányban elmaradt, ${ }^{10}$ így a konkrét szakaszokra utaló szabályozás maximum analóg módon volt alkalmazható.

Büntető anyagi jogi szabályait pedig az 1870. május 31-én elfogadott német büntető törvénykönyv megfelelö szakaszai alkották, melynek a fentebb felsorolt büncselekményekröl szóló szakaszai váltották fel a korábbi szabályozást. Ezek a szakaszok egységesen úgy rendelkeztek, hogy e büncselekmények esetében az életfogytiglan tartó fegyházzal büntetendő cselekmények hadiállapot idején halálbüntetéssel sújtandók. ${ }^{11}$

\section{AZ OSZTRÁK KIVÉTELES HATALOM SZÜLETÉSE, RENDSZERE ÉS FEJLŐDÉSE 1914-IG}

Az Osztrák Császárság a némethez nagyban hasonló kivételes hatalmi rendszert alakított ki. A Habsburgok a neoabszolutizmus éveit követően a sorozatos katonai vereségek hatására kiegyezésre kényszerültek a Magyar Királysággal, valamint alkotmányos reformot kellett végrehajtaniuk a koronatartományok tekintetében. Az 1867. december 21-én kiadott decemberi alkotmány több alkotmánylevélből álló alkotmányos struktúrát hozott létre. ${ }^{12}$ Ennek részeként szabályozták az alapvető jogokat. A törvény 20. cikke kimondta, hogy a személyes szabadság, a magánlakáshoz való jog, a levéltitok, az egyesülési és gyülekezési jog, valamint a sajtószabadság a végrehajtó hatalom részéről ideiglenesen korlátozható, annak részletes szabályait külön törvény állapítja meg. A kivételes hatalomról rendelkező törvényt 1869. május 5-én fogadták el. A kivételes hatalmat az összminisztérium rendeletével nyilvánították ki, amelyhez a császár hozzájárulása volt szükséges. A rendeletet közzé kellett tenni a birodalmi törvénytárban. Kivételes hatalom elrendelhető volt háború vagy annak közvetlen veszélye, továbbá belső zavarok esetén, vagyis amikor felségsértő vagy alkotmányt fenyegető, avagy személyes biztonságot veszélyeztető cselekmények tömegesen vagy kiterjedten fordultak elö. ${ }^{13}$

\footnotetext{
${ }^{9}$ Ereky István: Rendkívüli kútfök. In: Ereky István (szerk.): Jogtörténeti és közigazgatási jogi tanulmányok. II. kötet. Sziklai Henrik Kiadása, Eperjes, 1917, 565-566. http://dlib.ogyk.hu/view/action/nmets.do?DOCCHOICE=1656580.

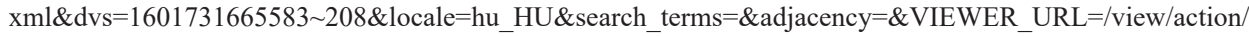
nmets.do?\&DELIVERY_RULE_ID=4\&divType= (Letöltés időpontja: 2020. 10. 03.)

${ }^{10}$ Lásd ennek okát bővebben Szabó István: Német alkotmányfejlődés 1806-1945 - Különös tekintettel az államszervezeti változásokra. Szent István Társulat, Budapest, 2002, 144-145.

11 Polner: i. m. 33.

12 Tamara Scheer: Die Ringstraßenfront Österreich-Ungarn, das Kriegsüberwachungsamt und der Ausnahmezustand während des Ersten Weltkrieges. Heeresgeschichtliches Museum, Wien, 2010, 11.

13 Polner: i. m. 38-39.
} 
Fontos eltérés a német szabályozáshoz képest, hogy az alapjogi korlátozás konkrét mértéket határozott meg, felső küszöbbel, amely „,kifejezett ellenkező rendelkezés hiányában a szabadságjogoknak a törvényben megállapított korlátozása lép a kivételes állapot elrendelésével önmagától hatályba”. ${ }^{14}$ Tehát míg német területeken a katonai parancsnokok szabadon határozhattak a korlátozás mértékről, addig az Osztrák Császárság vonatkozásában a törvényi szinttől csak enyhébb szabályokat állapíthattak meg. Ezzel itt is lehetővé tették a kialakult helyzethez igazítható alapjogi korlátozást.

A törvény tehát garanciális kereteket teremtve részletezte, hogy a fenti alapjogok milyen terjedelemben korlátozhatóak. A személyes szabadság esetében a bírói ítélet nélkül letartóztatott egyént az illetékes hatóságnak 48 órán belül át kellett adni, ez kivételes hatalom időszakában nyolc napra módosult. A törvény úgy rendelkezett, hogy meghatározott egyének óvadék ellenében sem helyezhetők szabadlábra. Emellett a közrend fenntartása érdekében a közigazgatási hatóságok - ha szükségesnek látták - elrendelhették egyes egyének kiutasítását vagy internálását.

A magánlakáshoz való jog akként módosult, hogy bizonyos büncselekmények esetében a házkutatás foganatosításához nem kellett bírói engedély. Az egyesülési jog korlátozása abban állt, hogy új egyesületet csak hatósági engedéllyel lehetett alapítani, régit pedig betilthatott a hatóság. Népgyüléseket egyáltalán nem, vagy csak hatósági engedéllyel lehetett tartani.

A sajtószabadság korlátozása területén számos lehetőség állt fent. Egyes nyomtatványok megjelenését vagy terjesztését be lehetett tiltani, a postai szállításhoz való jogot közigazgatási úton meg lehetett vonni, a nyomtatvány müködése beszüntethető volt. Emellett elrendelhetővé tették, hogy időszaki sajtótermékek a megjelenés után három órával, egyéb nyomtatványok pedig nyolc nappal később váltak terjeszthetővé.

Korlátozták továbbá fegyverek és lőszerek gyártását, eladását, birtoklását és hordását, továbbá az útlevelek igénylését és a bejelentkezéseket, valamint a nyilvános helyeken történő szabályellenes magaviseletet és csoportosulást. Ezek megszegése kihágásnak minősült, amit pénzbüntetéssel és hat hónapig terjedő elzárással sújtottak. ${ }^{15}$

Emellett garanciális elemként megjelent az, hogy az elrendelt intézkedésekről a Birodalmi Gyülést indokolást tartalmazó előterjesztésben tájékoztatni kellett, ennek elmaradása esetén a rendelkezések érvénytelenné váltak.

A fentieken túl egy 1873-as törvény lehetővé tette az esküdtbíróságok ideiglenes felfüggesztését. ${ }^{16}$ A büntető perjogról szóló törvény pedig büntetőjogi kivételes állapoti szabályokat állapított meg, amelyek révén az eljárás gyorsult és a végrehajtást jogorvoslat nélkül kellett foganatosítani. A közös katonai bünvádi perrendtartás az állam hadereje elleni büncselekmények esetén kimondta, hogy ilyen cselekmények megvalósítói - polgári személyek esetén is - katonai bíróságok által ítéltetnek meg. Ehhez viszont a kivételes állapot mellett szükség volt az igazságügyi miniszter általi kihirdetésére is. ${ }^{17}$

Az alkotmány szintén biztosította a rendeletalkotási lehetőséget. Ennek körében el kell határolni a kivételes rendeletet a szükségrendelettől. Utóbbi - föszabály szerint - nem kivételes hatalmi eszköz volt, hanem békeidőben, amikor a jogszabály megalkotásának sürgető szükségessége állt fenn és a Birodalmi Gyülés nem ülésezett, akkor adhattak ki ilyen rendeletet,

\footnotetext{
${ }^{14}$ Buza László: Az államjogi kivételes állapot III. Jogtudományi Közlöny, 50. évf. 1915/32., 351. http://real-j.mtak. hu/2183/1/JogtudomanyiKozlony_1915.pdf (Letöltés időpontja: 2020. 10. 03.)

${ }^{15}$ Uo.

${ }^{16}$ Wilhelm Brauneder: Osztrák alkotmánytörténet napjainkig. JPTE Állam- és Jogtudományi Kar, Pécs, 1994, 204.

${ }^{17}$ Buza László: Az államjogi kivételes állapot III. 351.
} 
amelynek ideiglenesen törvényereje volt. „Ilyenkor a végrehajtó hatalom-feltéve, hogy az alkotmányjog által megvont határok közt mozog - a szükségrendelet kiadásával olyan jogot gyakorol, amely öt az alkotmány értelmében megilleti. Az a hatáskör, melyben eljár, a saját hatásköre: a törvényhozó hatalom által ideiglenesen ráruházott hatáskör. A végrehajtó hatalom itt nem lépi túl a maga hatáskörét és nem követ el alkotmánysértést..." ${ }^{18}$ A német szabályozástól eltérően ezt a rendeletet a törvényhozásnak meg kellett később erősítenie. ${ }^{19}$ A kivételes rendeletet viszont csak a fentebb már felvázolt időszakokban lehetett megalkotni. Alkotmányos felhatalmazás alapján a minisztertanács adta ki a császár előzetes beleegyezésével. Ideiglenes hatályú volt, kizárólag a vészidőszakra vonatkozott. A törvényhozásnak szintén be kellett mutatni, ennek elmaradása ipso iure érvénytelenné tette, lényegében az alapjogok felfüggesztésének tényleges kereteit, a korlátozások hatályát rendezték benne. ${ }^{20}$

Utóbbi okán vált szükségessé, hogy a szükségrendeletek alkotását felhasználják kivételes hatalom idején is. Ezt a törvénypótló jogkört felhasználva adott a hadüzenet után Galícia, Bukovina, Szilézia és Morvaország vonatkozásában olyan jogot a legfőbb katonai parancsnoknak, hogy az „a katonai érdekeknek a politikai közigazgatás terén leendő megóvása végett a tartományi fönökök (helytartók, tartományi elnökök) hatáskörében rendeleteket bocsáthasson ki, parancsokat adhasson és ezek megtartását kikényszerithesse; a tartományi fönököket és alsóbb fokú közigazgatási hatóságokat pedig kötelezte, hogy a katonai legföbb parancsnok által kiadott rendeleteket megtartsák és végrehajtsák". ${ }^{21}$ Az alkotmány ugyanis nem tette lehetővé a katonai igazgatás polgári igazgatás fölé emelését és a polgári közigazgatási ${ }^{22}$ hatáskörök gyakorlását, tehát a szükségrendelet-alkotási jogosítvány felhasználásával de facto és de iure törvényt alkotott a végrehajtó hatalom a jogosítvány megszerzése érdekében. A hadigazdálkodás területén szintén jogosítványok hiányában 1914-ben és 1917-ben szükségrendeletet alkottak meg. A fentiektől annyi eltéréssel, hogy ezt a kormány kezdeményezte. Célja, hogy ,, a háború okozta rendkívüli viszonyok időtartamára a gazdasági élet támogatásához és talpra állitásához szükséges rendelkezéseket rendelet útján"”23 a kormány meg tudja tenni.

A kialakult osztrák kivételes hatalmi rendszer immanens részét képezte a kivételes hatalmi rendelkezéseket és szabályokat összefoglaló kivételes állapoti tájékoztató, amely anyagi, eljárási és szervezeti szabályokat is tartalmazott. Ennek kidolgozása 1904. március 15-én vette kezdetét, amikor Friedrich von Beck-Rzikowsky vezérkari főnök a mozgósítási és hadireform bizottság elnökeként utasította a Hadügyminisztérium több osztályát egy tervezet kidolgozására. Ennek során 1905-ben több egyeztetés történt a polgári és a katonai minisztériumok között. Az elveiben elkészült tervezetet Heinrich Ritter von Pitreich hadügyminiszter 1905. november 14-én azzal adta át Artur Bylandt-Rheidt osztrák belügyminiszternek, hogy terjessze azt az osztrák minisztertanács elé, és a lehető leggyorsabban fogadják el. A cél az volt, hogy ezt követően egy ugyanilyen csomagot összeállítsanak a magyar korona országai és Bosznia részére, megteremtve ezzel egy homogén kivételes hatalmi rendszert az egész

${ }^{18}$ Buza László: Az államjogi kivételes állapot I. Jogtudományi Közlöny, 50. évf. 1915/27., 306. http://real-j.mtak. hu/2183/1/JogtudomanyiKozlony_1915.pdf (Letöltés időpontja: 2020. 10. 03.)

19 Brauneder: i. m. 220.

${ }^{20}$ Ereky: i. m. 553-564.

${ }^{21}$ Polner: i. m. 38.

22 Az osztrák polgári közigazgatást lásd bővebben Pétervári Máté: Az Osztrák-Magyar Monarchia alsó középszintű közigazgatása a kiegyezést követően. Acta Juridica et Politica, IX. évf. 2019/1., 115-125. http://publicatio.bibl. u-szeged.hu/19178/1/OMMalsokozepszintukozigazgatasa.pdf (Letöltés időpontja: 2020. 10. 04.)

${ }^{23}$ Brauneder: i. m. 206. 
Monarchiára vonatkozóan. Az első kivételes állapoti tájékoztató 1906 elején készült el, amelynek kidolgozása során észlelték, hogy a szabályanyag óriási terjedelme és a rendkívül nagyszámú feladat okán szükséges lesz egy koordináló szerv létrehozása, amelyet Háborús Információs Irodának neveztek el (Kriegsinformationsamt). Ezt az elnevezést azonban Eugen Hordliczka, az Evidenzbüro vezetője nem tartotta megfelelőnek, mert az nem fedte a felállítandó szerv tényleges tevékenységét. ${ }^{24}$

A tájékoztató kivételes állapot idejére végleges formában 1906. augusztus 31-re készült el. Ezzel párhuzamosan megkezdték a tájékoztató kidolgozását Bosznia részére, és megküldték a csomagot Magyarországra is, ahol októberben adták ki. A központi közigazgatási szerveken túl a hadtestparancsnokságok, az erődítmények parancsnokai, valamint a posta- és távírda-igazgatóság kapták meg. A célja az volt, hogy mozgósítás esetén ezek a szervek már tudják, hogy milyen feladatokat kell ellátniuk, így ennek ismeretében következő év áprilisáig ki kellett dolgozniuk egy saját intézkedési tervet is. A tájékoztató emellett rendelkezett a Hadfelügyeleti Hivatal (Kriegsüberwachungsamt) kivételes állapoti felállításáról is. ${ }^{25}$

A tájékoztató felülvizsgálata az átalakult nemzetközi viszonyok - például Bosznia annektálásának nemzetközi visszhangja - okán 1908 októberében kezdődött meg. A tájékoztató kivételes állapot időszakára második kiadása 1909-ben készült el. Ez már egyértelmű tartalommal töltötte meg az osztrák kivételes hatalmi rendszert, ugyanis az alkotmányos rendszer egyes alapjogok korlátozásán és a rendeletalkotáson túl tényleges szabályanyagot nem adott kivételes állapot időszakára. Tehát míg a német rendszer alapjogi oldalon volt féloldalas, addig az osztrák hatásköri oldalon. Ezt orvosolta a tájékoztató, amely viszont alkotmányos deficitet teremtett ezzel, amit az alkotmány 14. §-a szerinti szükségrendeletalkotással orvosoltak.

A tájékoztató úgy rendelkezett, hogy a végrehajtó hatásköröket át kell adni a haderőnek, és a katonai joghatóságot ki kell terjeszteni a civilekre. Lehetővé tette a nyomdatermékek vizsgálatát és a távírda-, posta- és telefonforgalom korlátozását, valamint a háborúhoz nélkülözhetetlen termékek kivitelének tilalmazását. Emellett szintén rendelkezett a Hadfelügyeleti Hivatal felállításáról. Ennek feladata az információk összegyüjtése; annak eljuttatása a megfelelő szervhez; együttmüködés megvalósitása; valamint utasítások, rendelkezések kiadása; továbbá a bécsi állami telefonhálózat felügyelete. Rögzítették, hogy egyes kérdésekben hozott döntéseit úgy kellett tekinteni, mintha a tárgy szerinti minisztérium adta volna ki, saját nevében azonban rendeletet nem bocsáthatott ki. Személyi állományának meghatározása során erős katonai befolyás alakult ki a szervezetén belül. Tevékenységét 24 órában kellett volna ellátnia. Felállítására viszont csak mozgósítás esetén kerülhetett volna sor. A tájékoztató szerint közös szervként jött volna létre a Hadfelügyeleti Hivatal, ezért felkérték a magyar minisztériumokat is tagok delegálására, azok viszont nem tettek eleget ennek, a horvát-szlavón-dalmát területek azonban képviseltették magukat. ${ }^{26}$

A tájékoztató harmadik - ténylegesen a háborúban is alkalmazott - kiadása 1912ben készült el. Moritz Freiherr von Auffenberg hadügyminiszter a császár elé történő felterjesztése során kérte a Hadfelügyeleti Hivatal mozgósítás elötti felállítását. Többletet jelentett az előző kiadáshoz képest emellett az, hogy lehetővé tette a cenzúrát, az ellenséges államokkal a postaforgalom megszakítását, valamint már nemcsak osztrák területen biztosította a polgári személyek feletti katonai joghatóságot, hanem Kelet-Galícia és Bukovina

\footnotetext{
${ }^{24}$ Scheer: i. m. 14-18.

${ }^{25}$ Uo. 19.

${ }^{26}$ Uo. $23-28$.
} 
területén is. Az uralkodó 1912. december 9-én Franc Rohr Freiherr von Dentát nevezte ki a Hadfelügyeleti Hivatal élére, amely így tényleges működését már a háború előtt másfél évvel megkezdhette. ${ }^{27}$

Az osztrák kivételes hatalmi rendszerben tehát az alapjogi korlátozások alkotmányosan és törvényi szinten körülhatároltak voltak, kereteit rögzítették. A végrehajtó hatalom vészidőszaki meghatározottsága azonban nem történt meg törvényi szinten. A kivételes rendeletalkotás az alapjogi rendelkezésekre korlátozódott. Így ezek tényleges definíciója a tájékoztató a kivételes állapot időszakára elnevezésü dokumentumban történt meg, amelynek egyes törvények által nem szabályozott rendelkezéseit a szükségrendeletalkotási hatáskörével élve maga a végrehajtó hatalom alkotta meg. Ezzel tette lehetővé többek között a katonai igazgatás polgári igazgatásra történő kiterjesztését, valamint a hadigazdálkodás szabályainak megalkotására történő felhatalmazást.

\section{ÖSSZEGZÉS}

A kontinentális modellben - az eredeti francia modelltől eltérően - a kivételes hatalmi szabályozás alkotmányosan determinált intézmény. Az alapvető szabályokat és tényállásokat az egyes alaptörvények rögzítik, míg a részletszabályokat törvényi szintre utalták. Emellett - a többi kivételes hatalmi rendszertől eltérően - a sajátos kontinentális modellt ezzel megteremtve a kezdetektől fogva lehetővé tették végszükség esetén a rendeleti kormányzást vagy szükségrendeletek megalkotását, mert úgy vélték, hogy „,magának az alkotmánynak kell tehát gondoskodnia arról, hogy a kormány még ilyen rendkívüli esetekben se legyen kénytelen törvénysértést elkövetni. Minthogy ez csak úgy lehetséges, ha az alkotmány egyenesen feljogositja a kormányt arra, hogy a törvények hatályát végszükség esetén a parlament hozzájárulása nélkül is felfüggeszthesse..."28

Lényegében a kialakult új modell sajátja, hogy abban erős végrehajtói túlsúly jelentkezett, mégpedig az uralkodó jogállása okán, melyben természetszerüen benne foglaltatott a kivételes rendelet megalkotása is. A katonai közigazgatás rátelepítése a helyi polgári közigazgatásra szintén sajátképi megoldás, hiszen ilyen terrénumban nem volt megfigyelhető sem az ostromállapot eredeti francia modelljénél, ahol a haderő inkább rendészeti funkciókat látott el, sem az Amerikai Egyesült Államokban, ahol főszabály szerint csak pótolhatta az éppen nem működő polgári közigazgatást, sem pedig a brit birodalom esetében, ahol belföldön szintén inkább rendészeti és hadigazdálkodással kapcsolatos feladatokat valósítottak meg. Szintén sajátos, hogy a rendszer a büntető anyagi jogi szabályokhoz is hozzányúl, és nem csak az eljárásjogi normákat módosítja.

A kontinentális modell tehát a fentiek alapján a következőkkel jellemezhető: a) kivételes hatalom alkotmányos determináltságú intézmény; b) alkotmányban rögzített alapjogok korlátozhatóságát teszi lehetővé; c) belső és külső veszélyhelyzetben egyaránt alkalmazható; d) széles körü a rendeletalkotási lehetőség a végrehajtó hatalom oldalán; e) erős a végrehajtói túlsúly, ami az államfó tradicionális jogain is alapult; f) a katonai közigazgatás polgári igazgatás fölé emelése; g) speciális büntető anyagi és eljárásjogi szabályok alkalmazása.

\footnotetext{
${ }^{27}$ Uo. 29-30.

28 Ereky: i. m. 564.
} 


\section{FELHASZNÁLT IRODALOM}

Brauneder, Wilhelm: Osztrák alkotmánytörténet napjainkig. JPTE Állam- és Jogtudományi Kar, Pécs, 1994.

Buza László: Az államjogi kivételes állapot I. Jogtudományi Közlöny, 50. évf. 1915/27., 305-306. http:// real-j.mtak.hu/2183/1/JogtudomanyiKozlony_1915.pdf

Buza László: Az államjogi kivételes állapot II. Jogtudományi Közlöny 50. évf. 1915/28., 313-314. http://real-j.mtak.hu/2183/1/JogtudomanyiKozlony_1915.pdf

Buza László: Az államjogi kivételes állapot III. Jogtudományi Közlöny, 50. évf. 1915/32., 350-351. http://real-j.mtak.hu/2183/1/JogtudomanyiKozlony_1915.pdf

Ereky István: Rendkívüli kútfök. In: Ereky István (szerk.): Jogtörténeti és közigazgatási jogi tanulmányok. II. kötet. Sziklai Henrik Kiadása, Eperjes, 1917, 544-631. http://dib.ogyk.hu/view/action/ nmets.do?DOCCHOICE $=1656580 . x \mathrm{ml} \& \mathrm{dvs}=1601731665583 \sim 208 \&$ locale $=$ hu_HU\&search_terms $=\&$ adjacency $=\&$ VIEWER_URL=/view/action/nmets.do? \&DELIVERY_RULE_ID=4\&divType $=$

Farkas Ádám: A [hon]védelmi alkotmány kialakulása a polgári Magyarországon 1867-1944. Zrínyi Kiadó, Budapest, 2019.

Farkas Ádám: A totalitás kora? Magyar Katonai Jogi és Hadijogi Társaság, Budapest, 2018. http:// www.hadijog.hu/wp-content/uploads/2018/08/FA_a_totalitas_kora_BJM_I.pdf

Farkas Ádám: Az állam fegyveres védelmének alapvonalai. Katonai Nemzetbiztonsági Szolgálat, Budapest, 2019.

Farkas Ádám - Till Szabolcs: A honvédelmi alkotmány és alkotmányosság alapkérdései Magyarországon. In: Farkas Ádám - Kádár Pál (szerk.): Magyarország katonai védelmének közjogi alapjai. Zrínyi Kiadó, Budapest, 2016, 40-71.

Pétervári Máté: Az Osztrák-Magyar Monarchia alsó középszintü közigazgatása a kiegyezést követöen. Acta Juridica et Politica, IX. évf. 2019/1., 115-125. http://publicatio.bibl.u-szeged.hu/19178/1/ OMMalsokozepszintukozigazgatasa.pdf

Polner Ödön: A háború esetére szóló kivételes hatalom alkotmányjogi jelentösége. Jogállam, 16. évf. 1917/1-2., 25-42.

Scheer, Tamara: Die Ringstraßenfront Österreich-Ungarn, das Kriegsüberwachungsamt und der Ausnahmezustand während des Ersten Weltkrieges. Heeresgeschichtliches Museum, Wien, 2010.

Szabó István: Német alkotmányfejlödés 1806-1945 - Különös tekintettel az államszervezeti változásokra. Szent István Társulat, Budapest, 2002.

Tóth Árpád: A kivételes állapot intézménye néhány burzsoá állam jogrendszerében kialakulásától az első világháború végégig. Acta Juridica et Politica 5. Fasc. 1981, 1-54. http://acta.bibl.u-szeged. hu/6476/1/juridpol_028_fasc_005_001-054.pdf 